\section{Press pleads for more basic science}

\section{Washington}

THE new US presidential science adviser D. Allan Bromley is "walking into a situation unparalleled in opportunity", according to US National Academy of Sciences president Frank Press, himself a presidential science adviser during the Carter presidency.

Bromley, Press said, will have a chance to accomplish real advances in the way the US science enterprise is financed and managed. Press, speaking in advance of his annual address to the members of the academy, said that the Bush administration's concern for maintaining US strengths in science and technology, coupled with the increased political power of the science advisory post, could make Bromley's tenure the most impressive in recent history.

Press's hints that the next few years may be a watershed for US science were borne out in perhaps the most sweeping of his yearly speeches to the members of the science academy. In marked contrast with last year's address (Nature 333, 1; 1988) in which he stressed the importance of setting priorities for science within the confines of a budget, Press called for doubling US spending on basic science over the next five years to $\$ 20,000$ million.

Press says that could be done by raising the growth rate of the basic science budget from 6 to 14 per cent per year, at a total cost to the United States of $\$ 10,000$ million. Such a hefty rise should be possible, says Press, if big expenditures are delayed until after the federal budget deficit is reduced.

To remove the barriers blocking the industrial benefits of such a large investment in science and technology, Press proposes the creation of a cabinet-level National Economic Security Council with the same powers over the high-technology economy that the National Security Council has over defence. His view is that the presidential science adviser would play a key role in directing the activities of the council.

Press also advocated a "national facilities act" to provide the infrastructure necessary for major science developments. The legislation would pay for refurbishing laboratories, instruments and equipment. Press estimates the equivalent of 50 new buildings could be had for $\$ 1,250$ million. Press also advocates the creation of 3,000 graduate fellowships in science and engineering, at a cost of $\$ 3,000$ million.

But Press's grand proposals may not be taken up as enthusiastically as he would wish by Congress and the Bush administration.President Reagan's stated goal to double the US National Science Foundation budget over five years has not yet been attained. But Press has the patience to wait: if his suggestions are not taken up this year, he plans to pursue them again in 1990.

Carol Ezzell

\title{
Presidential adviser named
}

\section{Boston \& Washington}

AFTER more than two months of delay and increasingly vocal protest from the scientific community, US President George Bush last week finally announced his choice of Yale University professor D. Allan

IMAGE
UNAVAILABLE
FOR COPYRIGHT
REASONS

D. Allan Bromley, new science adviser.

Bromley for the post of presidential science adviser.

Bromley's appointment continues a tradition of favouring physicists for the post of adviser to the president and director of the Office of Science and Technology Policy. Bromley, who will be 63 next week, is Henry Ford II Professor of Physics and director of the A.W. Wright Nuclear Structure Laboratory at Yale University. He was born in Canada and has a high reputation in heavy-ion physics where he has been active in the development of accelerators, detectors and computer-based data collection and analysis systems.

Bush's failure to keep his promise to select a science adviser early in his administration had already prompted congressional protest by the time of the Bromley appointment. On 6 April, at a hearing of the Senate Labor and Human Resources Committee called by Senator Edward Kennedy (Democrat, Massachusetts), a series of witnesses, including Frank Press, president of the National Academy of Sciences, and two former science advisers, Donald Hornig and Guy Stever, expressed their disappointment that a science adviser had still not been appointed and that few of the 500 key federal administrative posts in science had been filled.

But Bromley says that Bush's campaign promise to upgrade the status of the science adviser is now to be fulfilled. Following "a discussion with the president" on 21 April, Bromley confirmed that "the new post will be the assistant to the president for science and technology. The science adviser will have direct access to the president and will be on the same level as the national security adviser [Brent Scowcroft].... This means that I will participate in meetings of the National Security Council, and I will be present at meetings that had not involved past science advisers." Bromley says he will not try to bring his own priorities to the job but rather "sharpen options for the president" and "be part of the president's team". "Any science adviser who is perceived as a spokesperson for the scientific community is doomed to failure", he says. "The science adviser must be trusted in all detail by the president, must participate in policy debate, and be present in high-level decisions that have a relevance to science and technological matters." Numerous problems with a strong scientific component face the president, including the need for decisions on the Strategic Defense Initiative, the space station, the Superconducting Super Collider, the project to map the human genome, the space plane, and international action to counter global atmospheric change.

Even more difficult, because the choices are not clear, will be the setting of national policy to restore the United States' technological superiority and industrial competitiveness in the face of the growing strength of Japan and Western Europe. "This issue leads quickly to concern for education and training", says Bromley. "The questions of science and technology today are integrated across a whole spectrum of governmental affairs. It is very different from Eisenhower's day when the position was created. Now, agencies across the board are very sophisticated in their use of science and technology." So many agencies are now involved in science that some experts believe that a science adviser cannot hope to have much impact and that a new science organization is required. In testimony before Senator Kennedy, Donald Hornig, former adviser to President Lyndon Johnson, pointed out that the Office of Science and Technology Policy has never had much influence over the National Institutes of Health, with their $\$ 7,000$ million budget, nor over the Department of Defense, where two-thirds of the federal research and development budget ( $\$ 42,000$ million) is spent.

The present science adviser. William Graham, claims to have spent much time nurturing inter-agency communication. But Graham's soft-spoken style gave him a reputation for near-invisibility. Colleagues of Bromley describe a man who is likely to act very differently, speaking of him as "emphatic", with new students initially "in awe of him".

Bromley directed former President Ronald Reagan's science and technology initiatives with India and Brazil and stresses the importance of international science. A key question, he says, is whether the United States should embark on huge projects "alone as a nation, or whether we should involve other countries".

Seth Shulman \& Alun Anderson 